\section{Nutrient and Water Use of Fresh Market Spinach}

\author{
Aaron Heinrich ${ }^{1}$, Richard Smith ${ }^{2,3}$, and Michael Cahn ${ }^{2}$
}

\begin{abstract}
AdDitionAl INDEX wORDs. nitrogen, phosphorus, potassium, nitrate "quick test," irrigation management, rooting density, rooting depth, nitrate leaching, crop evapotranspiration, crop coefficient

SUMMARY. In recent years, vegetable growers on the central coast of California have come under increasing regulatory pressure to improve nutrient management and reduce nitrate losses to ground and surface waters. To achieve this goal, growers must understand the nutrient uptake and water use characteristics of their crops. For fresh market spinach (Spinacia olevacea), production methods and cultivars have greatly changed in the last 10-15 years, and as a result, few publications are available on nutrient uptake by modern spinach production methods. This study evaluated nutrient uptake and water use by spinach to provide strategies to better manage nitrogen (N) fertilizer and irrigation applications. In 2011 , four fertilizer trials and a survey of 11 commercial fields of spinach grown on high-density plantings on 80-inch beds were conducted on the central coast of California. During the first 2 weeks of the crop cycle, $N$, phosphorus (P), and potassium (K) uptake was $7.0,0.6$, and $7.2 \mathrm{lb} /$ acre, respectively. In the subsequent $2-3$ weeks before harvest the $\mathrm{N}, \mathrm{P}$, and $\mathrm{K}$ uptake rate was linear and was 4.3, 0.6 , and $7.8 \mathrm{lb} /$ acre per day, respectively. $\mathrm{N}$ uptake at harvest for the three commercial size categories baby, teenage, and bunch was 74,91, and $120 \mathrm{lb} /$ acre $\mathrm{N}$, respectively. Of the $\mathrm{N}$ in aboveground biomass at harvest, $41 \%$ was left in the field following mechanical or hand harvest. Growers at 14 of 15 study sites applied on average $111 \%$ more $\mathrm{N}$ than was taken up in aboveground biomass at harvest. Results from four fertility trials showed that first crops of the season had low initial soil nitrate concentrations ( $\leq 10 \mathrm{ppm})$, and an at-planting fertilizer application was necessary for maximum yields. For fields following a previous crop (second- or third-cropped) with initial soil nitrate concentrations $>20$ ppm, at-planting and midseason fertilizer applications could be greatly reduced or eliminated without jeopardizing yield. Rooting depth and density evaluations at four sites showed that $95 \%$ of roots were located in the top 16 inches of soil at harvest. To mitigate environmentally negative $\mathrm{N}$ losses, the $\mathrm{N}$ use efficiency (NUE) can be increased by the use of soil testing done at two critical time points: at-planting and before the first midseason fertilizer application.
\end{abstract}

I n California, fresh-market spinach is grown throughout the year and accounts for $59 \%$ of the total U.S. fresh market production [U.S. Department of Agriculture (USDA), 2012]. In 2010, there were 26,900 acres of fresh market spinach grown in California (USDA, 2011). Spinach is marketed as three commodities: 1) fresh market clipped and bagged (clipped), 2) fresh market bunched, and 3 ) frozen. Clipped spinach is the

We thank the growers that worked with us on this project. Special thanks go to Barry Farrara, Adam Coleman, Thomas Lockhart, Felipe Ochoa, and Laura Murphy for their invaluable help with fieldwork. We also thank Timothy Hartz and Stuart Pettygrove for their review of the manuscript. This project was funded by the California Leafy Greens Research Board.

${ }^{1}$ Oregon State University, 4017 Agriculture and Life Sciences Building, Corvallis, OR 97333

${ }^{2}$ University of California Cooperative Extension, Monterey County, 1432 Abbott Street, Salinas, CA 93901

${ }^{3}$ Corresponding author. E-mail: rifsmith@ucanr.edu. dominant spinach produced in $\mathrm{Cal}$ ifornia and is sold as either small, young leaves (baby) or slightly older, medium-sized leaves (teenage). Clipped spinach as well as a large proportion of bunched product is grown on 80 -inch-wide beds planted at 1.54.0 million seeds/acre. Occasionally, the clipped spinach fields are regrown for harvest for the freezer industry.
Spinach is a high-value crop that requires sufficient $\mathrm{N}$ fertilizer and irrigation to ensure optimal growth and to meet high quality criteria (e.g., deep green leaf color). These production practices combined with a shallow root system (Schenk et al., 1991) and short production cycle (typically $30 \mathrm{~d}$ ) increase the potential of nitrate $\left(\mathrm{NO}_{3}\right)$ leaching. Water quality monitoring in coastal vegetable production areas has shown widespread incidences of $\mathrm{NO}_{3}$ levels that exceed the Federal Drinking Water standard of $10 \mathrm{mg} \cdot \mathrm{L}^{-1} \mathrm{NO}_{3}-\mathrm{N}$ (Harter and Lund, 2012). As a result, growers have come under increasing regulatory pressure to improve crop NUE and thereby minimize $\mathrm{NO}_{3}$ losses from production fields.

Producers can improve NUE by applying fertilizer at the optimal time and rate to match crop $\mathrm{N}$ uptake. However, the data necessary to make these fertilizer decisions for spinach is lacking. A few studies have reported $\mathrm{N}$ uptake of spinach (Canali et al., 2008, 2011), but no studies have evaluated high-density planting of clipped or bunched spinach grown on 80 -inch beds. This study was undertaken to provide data on the $\mathrm{N}$ uptake characteristics of spinach and evaluate ways to improve $\mathrm{N}$ fertilizer management.

To maximize the NUE of spinach production, it is necessary to account for the levels of residual soil $\mathrm{NO}_{3}$ and adjust fertilizer rates accordingly. In coastal California, two or three crops are grown during the yearly production cycle. Higher $\mathrm{N}$ fertilization rates are usually needed in first-cropped fields in spring because of low $\mathrm{NO}_{3}$ concentrations following leaching in wet winters and also because of cool soil conditions that limit soil $\mathrm{N}$ mineralization from soil organic matter. Later in the growing season, fertilizer $\mathrm{N}$ applications can often be less in the

\begin{tabular}{llll}
\hline $\begin{array}{l}\text { Units } \\
\begin{array}{l}\text { To convert U.S. to SI, } \\
\text { multiply by }\end{array}\end{array}$ & U.S.unit & SI unit & $\begin{array}{l}\text { To convert SI to U.S., } \\
\text { multiply by }\end{array}$ \\
\hline 0.4047 & $\mathrm{acre}(\mathrm{s})$ & $\mathrm{ha}$ & 2.4711 \\
29.5735 & $\mathrm{fl} \mathrm{oz}$ & $\mathrm{mL}$ & 0.0338 \\
0.3048 & $\mathrm{ft}$ & $\mathrm{m}$ & 3.2808 \\
0.0929 & $\mathrm{ft}^{2}$ & $\mathrm{~m}^{2}$ & 10.7639 \\
2.54 & inch $(\mathrm{es})$ & $\mathrm{cm}$ & 0.3937 \\
1.1209 & $\mathrm{lb} / \mathrm{acre}$ & $\mathrm{kg} \cdot \mathrm{ha}^{-1}$ & 0.8922 \\
1 & micron & $\mu \mathrm{m}$ & 1 \\
28.3495 & $\mathrm{oz}$ & $\mathrm{g}$ & 0.0353 \\
1 & $\mathrm{ppm}$ & $\mathrm{mg} \cdot \mathrm{kg}^{-1}$ & 1 \\
1 & $\mathrm{ppm}$ & $\mathrm{mg} \cdot \mathrm{L}^{-1}$ & $\mathrm{l}$ \\
2.2417 & ton/acre & $\mathrm{Mg} \cdot \mathrm{ha}^{-1}$ & 0.4461
\end{tabular}


second or third crop than the first crop because residual fertilizer $\mathrm{N}$ carryover and increased $\mathrm{N}$ mineralization of prior crop residues and soil organic matter increase the pool of soil $\mathrm{NO}_{3}$ available to the subsequent crop (Breschini and Hartz, 2002; Jackson et al., 1994).

Finally, little information is available concerning the water requirements of spinach under the common production systems used on the central coast of California. High-density plantings of spinach for clipped product are irrigated with overhead sprinklers. Spinach yield and quality is sensitive to deficits in soil moisture (Thompson and Doerge, 1995), and consequently growers may apply more water than the evapotranspiration (ET) demand of the crop. The combination of high soil $\mathrm{NO}_{3}$ levels combined with drainage from over-irrigating would presumably result in leaching of soil $\mathrm{NO}_{3}-\mathrm{N}$.

The objectives of this study were to l) understand the nutrient uptake characteristics for fresh market spinach grown at high density on 80-inchwide beds, 2) evaluate how fertilizer application rates and timing influence the growth and $\mathrm{N}$ uptake of spinach in first- and second-cropped fields with low and high residual soil $\mathrm{NO}_{3}$ concentrations, 3 ) evaluate water applications to production fields relative to crop ET, and 4) provide $\mathrm{N}$ management strategies to increase the NUE of spinach. To meet these objectives, grower fertilizer programs were evaluated and spinach $\mathrm{N}$ uptake was measured for sites over an entire production season with a range of soil and climatic conditions, and cropping histories. In addition, four replicated fertilizer trials were conducted on first- and secondcropped fields.

\section{Materials and methods}

SURVEY SITES. Eleven commercial field sites in the Salinas Valley (Monterey County) and in the San Juan Valley (San Benito County) of California were evaluated in 2011 for spinach growth and $\mathrm{N}$ uptake (Table $\mathrm{l}$ ). Eight sites were mechanically harvested for fresh market clipped products: baby (2- to 3.5-inch leaf length) and teenage (3.5- to 4.5-inch leaf length); and three hand harvested sites for fresh market bunch. All fields were sprinkler irrigated over the growth cycle. Spinach was planted in 18-32 seed lines on 80 -inch-wide beds at a density of 2-3.5 million seeds/acre.
Biomass samples were collected one to five times during the crop cycle from each site; samples were collected from a $15-\mathrm{ft}^{2}$ area and replicated three to four times. The entire plant was collected (including crown and cotyledons) by under cutting the spinach with knives, which typically left about 0.25 inch of hypocotyl on the plants. If wet soil adhered to plant tissue, the spinach was washed and blot dried before weighing. Crop residue left in fields following mechanical or hand harvest was measured using the same area and methods described above.

Soil samples for mineral $\mathrm{N}$ were collected from 0 - to 12 -inch depth on the same day as the biomass samples. Field moist soil was added to a $2 \mathrm{M}$ potassium chloride $(\mathrm{KCl})$ solution at a ratio of $1 \mathrm{~g}$ soil to $5 \mathrm{~mL}$ of $\mathrm{KCl}$. The clear supernatant was extracted and the solution was analyzed by the University of California Davis Analytical Laboratory [UCDAL (Davis, CA)] for $\mathrm{NO}_{3}$ (Knepel, 2003) and ammonium $\left[\mathrm{NH}_{4}\right.$ (Hofer, 2003)]. Dried plant samples were ground using a Wiley mill to pass a 40 -mesh screen $(420 \mu \mathrm{m})$ and the samples were sent to UCDAL for total $\mathrm{N}$ analysis by combustion (AOAC International, 2006) and

Table 1. Site and production information for commercial spinach fields surveyed in 2011 in the Salinas Valley and San Juan Valley of California. First-cropped fields (first) indicate that the crop was the first of the production season after winter fallow. Second-and third-cropped fields (second and third) followed a previous vegetable crop. All nitrogen (N) applications were applied by the grower.

\begin{tabular}{|c|c|c|c|c|c|c|c|c|}
\hline Site $^{\mathrm{z}}$ & Cultivar & Crop & $\begin{array}{c}\text { Soil } \\
\text { texture }^{y}\end{array}$ & $\begin{array}{l}\text { Wet } \\
\text { date }\end{array}$ & $\begin{array}{l}\text { In-season } \\
\text { application } \\
\text { method }^{x}\end{array}$ & $\begin{array}{l}\mathrm{N} \text { applied } \\
\text { at-planting } \\
(\mathrm{lb} / \mathrm{acre})^{\mathrm{w}}\end{array}$ & $\begin{array}{l}\mathrm{N} \text { applied } \\
\text { in-season } \\
\text { (lb/acre) }\end{array}$ & $\begin{array}{c}\text { Total N } \\
\text { applied } \\
\text { (lb/acre) }\end{array}$ \\
\hline 1 & Reflect & First & $\mathrm{scl}$ & 9 Mar. & Sprinkler & 80 & 150 & 230 \\
\hline 3 & Mississipi & First & $\mathrm{cl}$ & 11 May & Topdress & 58 & 145 & 203 \\
\hline 4 & Mississipi & First & $\mathrm{scl}$ & 31 May & Topdress & 58 & 102 & 160 \\
\hline 7 & Mississipi & Second & sl & 10 Sept. & Topdress & 64 & 138 & 202 \\
\hline 8 & Mississipi & Second & sl & 14 Sept. & Topdress & 64 & 138 & 202 \\
\hline 9 & Avenger & Second & $\mathrm{cl}$ & 17 Sept. & Topdress & 80 & 86 & 166 \\
\hline 10 & Avenger & Third & sl & 25 Sept. & Sprinkler & 80 & 86 & 166 \\
\hline 11 & El Real & Second & $\mathrm{cl}$ & 22 Sept. & Topdress & 100 & 100 & 200 \\
\hline Trial 1 & Lazio & First & sl & 16 Apr. & Top/sprinkler & 80 & 134 & 214 \\
\hline & & & & & First crop & 73 & 118 & 191 \\
\hline & & & & & Second, third crop & 59 & 105 & 164 \\
\hline
\end{tabular}

${ }^{2}$ Sites $1-11$ are survey sites and trial $1-4$ are fertilizer trials (values shown are from the grower standard treatment).

${ }^{y_{\mathrm{SCl}}}=$ silty clay loam, $\mathrm{l}=$ loam, sil $=$ silt loam, $\mathrm{cl}=$ clay loam, $\mathrm{sl}=$ sandy loam, $\mathrm{c}=$ clay

${ }^{\mathrm{x}}$ sprinkler $=$ fertilizer injected into the sprinkler irrigation system, topdress $=$ dry fertilizer applied over top of the crop and watered into the soil

wl lb/acre $=1.1209 \mathrm{~kg} \cdot \mathrm{ha}^{-1}$. 
selected samples were also analyzed for P and K (Meyer and Keliher, 1992; Sah and Miller, 1992). Soil texture was determined using the hydrometer method (Bouyoucos, 1962).

Fertilizer trials. Four fertilizer trials were conducted in commercial fields in Spring through Fall 201 1: three in the Salinas Valley and one in the San Juan Valley. The effect of atplanting $\mathrm{N}$ rates on yield was evaluated for three of the trials (trials 1,2 , and 4 ), while trial 3 received only a midseason topdress fertilizer application. Each trial consisted of a grower standard (Std) practice and four fertilizer treatments: ammonium sulfate applied at a rate of $0,20,40,80 \mathrm{lb} /$ acre $\mathrm{N}$, (AS0, AS20, AS40, and AS80, respectively). Ammonium sulfate was chosen as the $\mathrm{N}$ source because the positively charged $\mathrm{NH}_{4}$ ion would initially be less susceptible to leaching losses with the germination water. The sulfur content of this fertilizer was not considered a confounding factor because soil and irrigation water sulfate content are sufficient for optimal crop growth in the intensive vegetable production fields of central California. Details for each replicated fertility trial site are given in Tables 1,2 , and 3 . For trials 1,2 , and 4 , fertilizer $(15 \mathrm{~N}-3.5 \mathrm{P}-3.3 \mathrm{~K}$ at $80 \mathrm{lb} /$ acre N) was sprayed over top of the Std treatment with a commercial rig at planting; the $15 \% \mathrm{~N}$ in this material was composed of $3.0 \% \mathrm{NO}_{3}$, $5.5 \% \mathrm{NH}_{4}$, and $6.5 \%$ urea. Each plot was one 80 -inch-bed wide by $20-\mathrm{ft}$ long and replicated four times (three times for trial 3 ) in a randomized complete block design. All fields were sprinkler irrigated throughout the growth cycle.

Applied water was measured using 6-inch-diameter propeller flow meters (McPropeller, McCrometer, Hemet, CA) positioned on the main irrigation lines. Canopy cover was estimated weekly from overhead photos taken at a 12 -ft height using a digital infrared camera (ADC; Tetracam, Chatsworth, CA). Crop ET (ETc) losses for spinach were estimated using daily reference ET data collected from the nearest California Irrigation Management Information System weather station multiplied by a crop coefficient

Table 2. Soil characteristics of replicated nitrogen $(\mathrm{N})$ fertilizer trials on spinach in the Salinas Valley and San Juan Valley of California.

\begin{tabular}{|c|c|c|c|c|c|}
\hline Trial & Soil type & $\mathrm{pH}$ & $\frac{\text { Olsen- } \mathrm{P}^{\mathrm{z}}}{\left(\mathrm{mg} \cdot \mathrm{kg}^{-1}\right.}$ & $\frac{\mathrm{X}-\mathrm{K}^{\mathrm{y}}}{\text { soil) }}$ & $\begin{array}{c}\text { Org- } C^{\mathrm{x}} \\
(\%)\end{array}$ \\
\hline 1 & Metz fine sandy loam (Typic Xerofluvents) & 7.6 & 22 & 180 & 0.6 \\
\hline 2 & Sorrento silty clay loam (Calcic Haploxerolls) & 7.3 & 66 & 378 & 1.9 \\
\hline 3 & Salinas loam (Pachic Haploxerolls) & 6.8 & 44 & 335 & 1.4 \\
\hline 4 & Metz fine sandy loam (Typic Xerofluvents) & 7.6 & 22 & 180 & 0.6 \\
\hline
\end{tabular}

${ }^{2}$ Olsen bicarbonate extractable phosphorus; $1 \mathrm{mg} \cdot \mathrm{kg}^{-1}=1 \mathrm{ppm}$.

'Extractable potassium by displacement using ammonium acetate buffered to $\mathrm{pH}$ 7.0.

${ }^{\mathrm{x}}$ Organic carbon by combustion.

(Kc). The Kc was estimated using the canopy cover data and procedures described by Gallardo et al., (1996) for lettuce (Lactuca sativa) where soil evaporation and crop transpiration were calculated separately.

Soil $\mathrm{NO}_{3}$ and $\mathrm{NH}_{4}$ were measured at weekly intervals from the 0 - to 12 -inch depth. Field moist soil was extracted with a $2 \mathrm{M} \mathrm{KCl}$ solution and analyzed as previously described for $\mathrm{NO}_{3}$ and $\mathrm{NH}_{4}$. Biomass and tissue $\mathrm{N}$ evaluations were made two to three times during the growth cycle from a $5.4-\mathrm{ft}^{2}$ area in each plot and plant samples were collected and processed as described above.

RoOT AND $\mathrm{NO}_{3}$ DISTRIBUtion. A root pit (32-inch wide by 24 -inch deep) was excavated at four sites (fertilizer trials 1,3 , and 4 and survey site 4) to evaluate rooting depth and density, and $\mathrm{NO}_{3}$ distribution in the soil profile. A smooth face was prepared on the excavated area and then a handpressurized sprayer (model no. 418IL; Solo, Newport News, VA) was used to wash soil from the roots. A grid with $484 \times 4$-inch sections was placed over the exposed soil and roots in each square were counted. Soil samples were collected from each grid and analyzed for $\mathrm{NO}_{3}$.

DATA ANALYSIS AND STATISTICS. Yield data were subjected to ANOVA in SAS (version 9.2; SAS Institute, Cary, NC) using the GLM procedure. Mean separation was determined using Fisher's least significant difference test $(P<0.05)$. Linear regression analysis was performed using SigmaPlot (version 12.0; Systat Software, San Jose, CA).

Table 3. Nitrogen (N) fertilizer applied to replicate trials in commercial spinach fields in the Salinas Valley and San Juan Valley of California. For trials 1, 2, and 4, four rates of ammonium sulfate were applied at-planting at 0, 20, 40, 80 lb/acre $\mathrm{N}$ (AS0, AS20, AS40, and AS80, respectively); midseason applications were grower applied at the rates indicated 2-4 weeks after planting. In trial 3, no at-planting $\mathbf{N}$ was applied and all treatments were applied 2 weeks after planting. All trials included a grower standard (Std) for comparison.

\begin{tabular}{|c|c|c|c|c|c|c|c|c|c|c|}
\hline \multirow{3}{*}{$\begin{array}{l}\text { At-planting } \\
\text { treatments }\end{array}$} & \multicolumn{3}{|c|}{ Trial 1} & \multicolumn{3}{|c|}{ Trial 2} & \multirow{2}{*}{$\frac{\text { Trial } 3}{\text { Mid-season }^{\mathbf{x}}}$} & \multicolumn{3}{|c|}{ Trial 4} \\
\hline & At-planting & Mid-season $^{z}$ & Total & At-planting & Mid-season $^{\mathrm{y}}$ & Total & & At-planting & Mid-season $^{\mathrm{w}}$ & Total \\
\hline & \multicolumn{10}{|c|}{$(\mathrm{lb} /$ acre $\mathrm{N})$} \\
\hline AS20 & 20 & 134 & 154 & 20 & 43 & 63 & 20 & 20 & 86 & 106 \\
\hline AS40 & 40 & 134 & 174 & 40 & 43 & 83 & 40 & 40 & 86 & 126 \\
\hline AS80 & 80 & 134 & 214 & 80 & 43 & 123 & 80 & 80 & 86 & 166 \\
\hline
\end{tabular}

${ }^{\mathrm{z}}$ Grower topdressed $63 \mathrm{lb} /$ acre $\mathrm{N}$ as ammonium sulfate, sprinkler applied $39 \mathrm{lb} /$ acre $\mathrm{N}$ as calcium nitrate, and sprinkler applied $32 \mathrm{lb} /$ acre $\mathrm{N}$ as calcium ammonium nitrate $(\mathrm{CAN17}) ; \mathrm{l} \mathrm{lb} / \mathrm{acre}=1.1209 \mathrm{~kg} \cdot \mathrm{ha}^{-1}$.

ysprinkler applied $43 \mathrm{lb} /$ acre $\mathrm{N}$ as CAN17.

${ }^{x}$ Trial 3 had no at-planting $\mathrm{N}$ applied; total $\mathrm{N}$ applied was applied as ammonium sulfate midseason $14 \mathrm{~d}$ after planting.

"Sprinkler applied $86 \mathrm{lb} /$ acre $\mathrm{N}$ as CAN17.

v $80 \mathrm{lb} /$ acre N applied at-planting to the Std treatment as $15 \mathrm{~N}-3.5 \mathrm{P}-3.3 \mathrm{~K}$ in trials 1,2 , and 4 . 


\section{Results and discussion}

Nutrient uptake. Mean N, P, and $\mathrm{K}$ uptake over a range of soil and climatic conditions during the 2011 production season (March-September) is shown in Table 4. The average days after germination water (DAGW) to harvest were 30 but varied by the time of year and the spinach product grown (Table 4). Spinach N uptake was 0.45 $\mathrm{lb} /$ acre per day $(7.0 \mathrm{lb} /$ acre $)$ in the first 2 weeks of the crop cycle (including the germination period) and increased to $4.3 \mathrm{lb} /$ acre per day $\left[\mathrm{R}^{2}=\right.$ 0.67 (Fig. 1A) ] in the 2 weeks before harvest. However, $\mathrm{N}$ uptake was even greater the week preceding harvest; during this part of the growth cycle mean $\mathrm{N}$ uptake was $7.3 \mathrm{lb} /$ acre per day and was as high as $10.0 \mathrm{lb} /$ acre per day for several fields. Graphing $\mathrm{N}$ uptake as a function of growing degree-days did not improve the coefficient of determination (data not shown).

More than $90 \%$ of total $\mathrm{N}$ uptake occurred from $\approx 2$ weeks after the germination water until harvest. At harvest, $\mathrm{N}$ uptake for baby, teenage, and bunch spinach averaged 74, 94, and $120 \mathrm{lb} /$ acre $\mathrm{N}$, respectively (Table 4). The $\mathrm{N}$ uptake for bunch spinach given here is likely an underestimation. Bunch fields were usually sampled on the first day of harvest, but bunch harvest may occur over a period of up to 1 week depending on field size and market demand. Additional days of growth could significantly increase $\mathrm{N}$ uptake.

The pattern of $\mathrm{K}$ uptake is similar to that for N (Fig. 1B), with a low K demand in the first 2 weeks of the cropping cycle $(0.52 \mathrm{lb} /$ acre per day) followed by a high $\mathrm{K}$ uptake rate $(7.8$ lb/acre per day) during the 2 weeks before harvest. At harvest, $\mathrm{K}$ uptake for baby, teenage, and bunch spinach were 76, 124, and $196 \mathrm{lb} /$ acre, respectively (Table 4 ) indicating a higher demand for $K$ than for $\mathrm{N}$. The demand for $\mathrm{P}$ was also low in the first 2 weeks with $0.05 \mathrm{lb} /$ acre per day removed by the crop. This was followed by a $\mathrm{P}$ uptake of $0.6 \mathrm{lb} /$ acre per day (Fig. 1C). At harvest, $\mathrm{P}$ uptake for baby, teenage, and bunch spinach was 6, 9, and $14 \mathrm{lb} /$ acre, respectively (Table 4 ).

N FERTILIZER Trials. Fertilizer trials 1 and 2 were first-cropped fields that were fallowed the preceding winter. Due to wet winter and spring conditions in 2010-11, initial soil mineral $\mathrm{N}$ concentrations were low $[<10$ $\mathrm{mg} \cdot \mathrm{kg}^{-1} \mathrm{NO}_{3}-\mathrm{N},<1.2 \mathrm{mg} \cdot \mathrm{kg}^{-1} \mathrm{NH}_{4}-\mathrm{N}$ (Fig. 2A and B)]. In trial 1 , following at-planting fertilizer applications, soil mineral $\mathrm{N}$ levels increased above 20 $\mathrm{mg} \cdot \mathrm{kg}^{-1}$ for treatments receiving $\geq 40$ $\mathrm{lb} / \mathrm{acre}$ ammonium sulfate, and remained above $20 \mathrm{mg} \cdot \mathrm{kg}^{-1}$ for the rest of the crop cycle for the two highest fertilizer treatments (Fig. 2A). This is at or above the $20-25 \mathrm{mg} \cdot \mathrm{kg}^{-1} \mathrm{NO}_{3}-\mathrm{N}$ threshold for $\mathrm{N}$ fertilizer response established for cool season vegetables in this region (Breschini and Hartz, 2002; Hartz et al., 2000). After the first biomass evaluation in trial 1 , there was not a statistical difference in biomass for treatments that received atplanting applications of $\geq 40 \mathrm{lb} /$ acre $\mathrm{N}$ (Fig. 3A). At harvest, there was not a statistical difference in tissue $\mathrm{N}$ content or $\mathrm{N}$ uptake between the three highest fertilizer treatments [AS40, AS80, and Std (data not shown)].

In trial 2 at-planting additions of ammonium sulfate did not increase soil mineral $\mathrm{N}$ concentrations as greatly as in trial $\mathrm{l}$ (Fig. 2A and B). Soil mineral $\mathrm{N}$ concentrations were at or above the $20 \mathrm{mg} \cdot \mathrm{kg}^{-1} \mathrm{NO}_{3}-\mathrm{N}$ threshold following the at-planting $\mathrm{N}$ addition in the high rate fertilizer treatments (AS80 and Std) only. Although soil mineral $\mathrm{N}$ concentrations were below the 20 $\mathrm{mg} \cdot \mathrm{kg}^{-1}$ threshold during most of the growing season for the lower rate fertilizer treatments (AS20 and AS40), there

Table 4. Harvest characteristics and total nitrogen $(\mathrm{N})$, phosphorus $(\mathrm{P})$, and potassium $(\mathrm{K})$ uptake, and $\mathrm{N}$ in residue and soil for commercial spinach fields sampled in 2011 in the Salinas Valley and San Juan Valley of California.

\begin{tabular}{|c|c|c|c|c|c|c|c|c|c|}
\hline Site $^{\mathrm{z}}$ & Product & $\begin{array}{l}\text { Harvest } \\
\text { (d) })^{y}\end{array}$ & $\begin{array}{l}\text { Fresh yield } \\
(\text { tons } / \text { acre })^{x}\end{array}$ & $\begin{array}{l}\text { Tissue } \mathrm{N} \\
\text { (\% total) }\end{array}$ & N uptake & $\frac{\text { P uptake }}{(\text { lb } / \text { acre })^{x}}$ & K uptake & $\begin{array}{l}\text { Residue } N \\
(\% \text { of total })^{w}\end{array}$ & $\begin{array}{c}\text { Mineral N } \\
\left(\mathrm{mg} \cdot \mathrm{kg}^{-1} \text { soil }\right)^{v}\end{array}$ \\
\hline 1 & Baby & 44 & 9.9 & 4.5 & 94 & $\mathrm{NA}$ & NA & 52 & 7 \\
\hline 3 & Teenage & 30 & 17.5 & 5.5 & 97 & NA & NA & 26 & 39 \\
\hline 4 & Bunch & 32 & 12.4 & 5.7 & 84 & $\mathrm{NA}$ & NA & 40 & 11 \\
\hline 5 & Bunch & 30 & 19.7 & 6.0 & 140 & 14 & 187 & 35 & 38 \\
\hline 8 & Teenage & 26 & 9.7 & 5.5 & 77 & 8 & 101 & 47 & 41 \\
\hline 9 & Baby & 26 & 7.5 & 5.8 & 63 & 7 & 101 & $\mathrm{NA}$ & 19 \\
\hline 10 & Teenage & 29 & 12.4 & 6.4 & 113 & 10 & 169 & 63 & 62 \\
\hline 11 & Baby & 33 & 5.9 & 5.7 & 60 & 6 & 50 & 51 & 44 \\
\hline Trial 1 & Teenage & 30 & 12.5 & 4.2 & 98 & NA & NA & NA & 40 \\
\hline \multirow{3}{*}{ Avg } & Baby & 32 & 8.9 & 5.1 & 74 & 6 & 76 & 45 & 25 \\
\hline & Teenage & 28 & 12.4 & 5.7 & 94 & 9 & 124 & 43 & 42 \\
\hline & Bunch & 34 & 16.3 & 5.8 & 120 & 14 & 196 & 35 & 25 \\
\hline
\end{tabular}

${ }^{\mathrm{z}}$ Fertilizer trials $1-4$ include data from the grower standard treatment.

'Days after first germination water.

${ }^{\mathrm{x}} \mathrm{l}$ ton $/ \mathrm{acre}=2.2417 \mathrm{Mg} \cdot \mathrm{ha}^{-1}, \mathrm{l} \mathrm{lb} /$ acre $=1.1209 \mathrm{~kg} \cdot \mathrm{ha}^{-1}$.

"Percentage of total crop $\mathrm{N}$ uptake that remains in the field a crop residue following commercial harvest.

${ }^{\mathrm{N}}$ Nitrate- $\mathrm{N}+$ ammonium $-\mathrm{N}$ in soil at harvest; $1 \mathrm{mg} \cdot \mathrm{kg}^{-1}=1 \mathrm{ppm}$. 


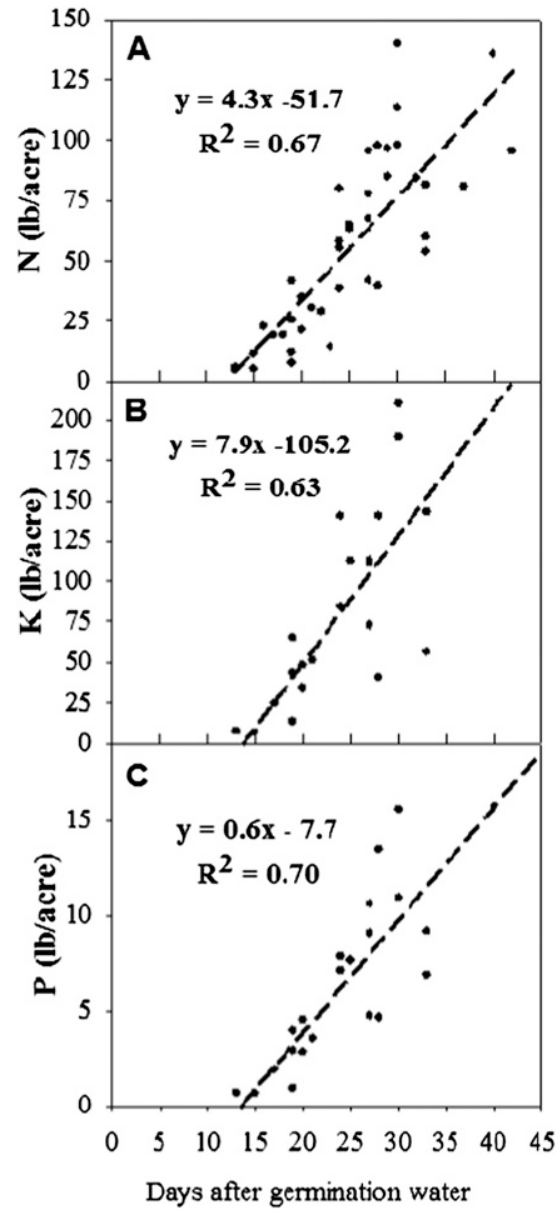

Fig. 1. Uptake in aboveground spinach biomass of (A) nitrogen $(\mathrm{N}),(\mathrm{B})$ potassium $(\mathrm{K})$, and $(\mathrm{C})$ phosphorus $(\mathrm{P})$ for fertilizer trials and survey sites in commercial spinach fields sampled in the Salinas Valley and San Juan Valley of California. Each point represents the average of three to four replicates. The dashed line is the best fit linear regression line; $1 \mathrm{lb} /$ acre $=1.1209$ $\mathrm{kg} \cdot \mathrm{ha}^{-1}$.

was no difference in biomass accumulation in the first $18 \mathrm{~d}$ of growth for all fertilizer treatments (Fig. 3B). As in trial 1 , there was not a statistical difference in biomass for treatments that received at-planting applications of $\geq 40 \mathrm{lb} /$ acre $\mathrm{N}$ (Fig. 3B). Also at harvest, there was not a statistical difference in tissue $\mathrm{N}$ content or $\mathrm{N}$ uptake between the three highest fertilizer treatments [AS40, AS80, and Std (data not shown)]. The lower yield at harvest in trial 2 compared with trial $\mathrm{l}$ is the result of harvesting the crop as a baby spinach product.

Trials 3 and 4 were second- and third-cropped fields, respectively, and there was no yield response to any of the fertilizer treatments (Fig. 3C and D) or difference in tissue $\mathrm{N}$ or $\mathrm{N}$ uptake among the treatments (results not shown). The at-planting residual soil $\mathrm{NO}_{3}$ concentrations in Trial 3 were $27 \mathrm{mg} \cdot \mathrm{kg}^{-1}$ and the grower decided to not make at-planting fertilizer $\mathrm{N}$ applications. Fertilizer $\mathrm{N}$ treatments were applied 2 weeks after planting (Table 3). Soil $\mathrm{NO}_{3}$ levels remained above $20 \mathrm{mg} \cdot \mathrm{kg}^{-1}$ until harvest for the three highest fertilizer treatments (Fig. 2C) and no yield response was observed in any of the fertilizer treatments (Fig. 3C). High residual soil $\mathrm{NO}_{3}$ levels were probably the result of residual fertilizer and $\mathrm{N}$ mineralization from prior crop residues.

In trial 4 , at-planting residual soil $\mathrm{NO}_{3}$ concentrations were $>20 \mathrm{mg} \cdot \mathrm{kg}^{-1}$ $\mathrm{N}$ (Fig. 2D), but the grower decided to apply at-planting fertilizer because he was concerned that much of this $\mathrm{NO}_{3}$ would leach when the germination water was applied to the coarsetextured sandy loam soil. Before the midseason fertilizer application 15 DAGW, all treatments were at or well above the $20 \mathrm{mg} \cdot \mathrm{kg}^{-1}$ soil $\mathrm{NO}_{3}$ threshold. The midseason fertilizer application of $86 \mathrm{lb} /$ acre $\mathrm{N}$ increased mineral $\mathrm{N}$ to high levels (Fig. 2D), which remained high until harvest. As in trial 3, there was no statistical difference in biomass (Fig. 3D), tissue $\mathrm{N}$, or $\mathrm{N}$ uptake among all treatments (data not shown).

Irrigation and ETc are shown in Table 5. Reference ET averaged 0.15 inches/d across all trial sites and ranged from 0.11 to 0.22 inches/d. The Kc for spinach during germination averaged 0.53 and increased to 0.85 by harvest. Growers applied water equal to $399 \%$ of ETc during germination, typically in three irrigations over a 6-d period. Growers applied an average of $122 \%$ of ETc after germination to harvest. On average, 5 inches of water was applied from seeding to harvest which was $192 \%$ of ETc.

Grower N FERTILIZER RATES AND TIMING. Grower applied atplanting fertilizer applications averaged $66 \mathrm{lb} /$ acre $\mathrm{N}$, with first-cropped fields receiving slightly more (Table 1 ). The average date for the first midseason fertilizer application was 16 DAGW. Although the growers did a good job synchronizing this fertilizer application with the rapid increase in spinach $\mathrm{N}$ uptake that began around $14 \mathrm{~d}$ (Fig. 1A), most growers did not considered soil $\mathrm{NO}_{3}$ concentrations when determining the fertilizer rate.

Only survey site 5 had more $\mathrm{N}$ in the biomass than was applied as fertilizer (Fig. 4). The grower at this site eliminated the at-planting fertilizer application based on a soil test that indicated sufficient residual soil $\mathrm{NO}_{3}$ for optimal crop growth. For the other 14 sites, growers applied an average of $111 \%$ more $\mathrm{N}$ than was taken up in aboveground biomass at harvest. As a result of these high fertilizer applications, residual mineral $\mathrm{N}$ concentrations were often moderate to high at harvest, especially for second-cropped spinach (Table 4). After harvest, soil $\mathrm{NO}_{3}$ concentrations are assumed to increase further because $41 \%$ of the total biomass $\mathrm{N}$ remains in the field after harvest (Table 4). This residue mineralizes rapidly when incorporated into the soil because the tissue is succulent (i.e., low lignin content) and has a high $\mathrm{N}$ content (about 5\% $\mathrm{N})$.

Root and $\mathrm{NO}_{3}$ Distribution. Spinach, when grown as a clipped product, has a shallow root system. At harvest $(\approx 30 \mathrm{DAGW}), 95 \%$ of all roots were located in the surfacel 6 inches (Table 6). Three of the four soil pits had a restrictive layer, due to a plow pan or textural change that may have prevented deeper root penetration. However, $96 \%$ of the roots recorded in trial 3 , which did not have a restrictive layer, were also found in the surfacel 6 inches, which indicates that even without an impeding layer, few roots extend below 16 inches. These results are similar to Schenk et al., (1991) where at harvest (6-week old plants) $80 \%$ and $15 \%$ of total spinach root length were located in the top 0-6 and 6-12 inches of soil, respectively.

At harvest, all sites showed increasing levels of soil $\mathrm{NO}_{3}$ below 12 inches (Table 7). This $\mathrm{NO}_{3}$ was unused by the spinach crop and would be at risk to $\mathrm{NO}_{3}$ leaching with the application of irrigation or rainfall amounts that are beyond the ability of the soil to retain the moisture.

IMPLICATIONS FOR $\mathbf{N}$ FERTILIZER MANAGEMENT OF FRESH MARKET SPINACH. Two to three vegetable crops are grown per year in the coastal vegetable production districts of California. This intensive production can result in high end-of-season residual $\mathrm{NO}_{3}$ concentrations, which 

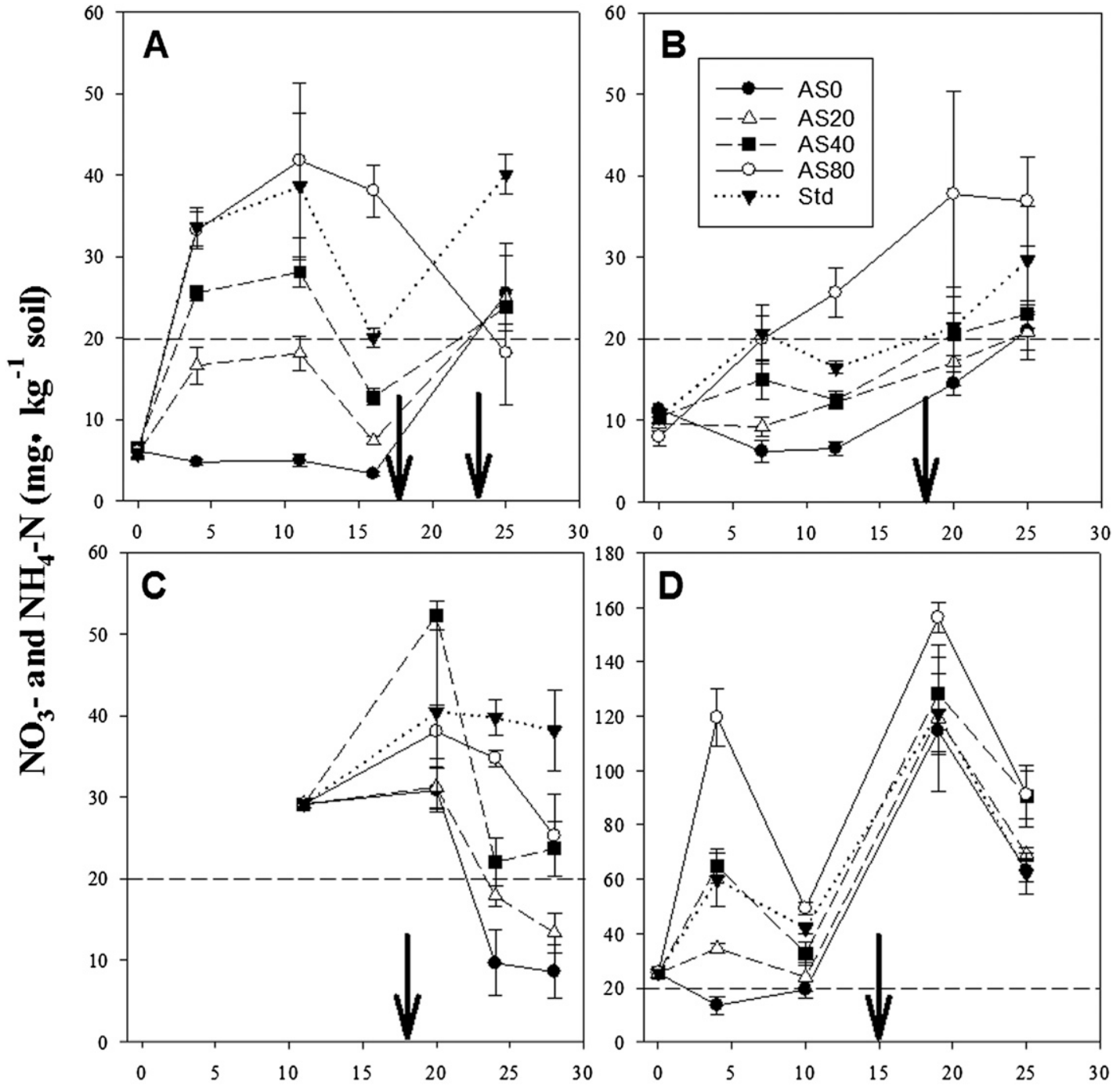

Days after first germination water

Fig. 2. Total mineral $\mathrm{N}$ [nitrate $\left(\mathrm{NO}_{3}\right)+\operatorname{ammonium}\left(\mathrm{NH}_{4}\right)$ ] concentrations for four replicated fertilizer trials in commercial spinach fields sampled in the Salinas Valley and San Juan Valley of California: (A) first-cropped fields trial 1, (B) trial 2, (C) second- and third-cropped fields trial 3, and (D) trial 4. The horizontal dashed line is at $20 \mathrm{mg} \cdot \mathrm{kg}^{-1} \mathrm{NO}$ - $\mathrm{N}$, which represents the soil $\mathrm{N}$ level above which no yield increase is expected (Breschini and Hartz, 2002; Hartz et al., 2000). Fertilizer treatments are $\mathrm{NH}_{4}$ sulfate applied at a rate of $0,20,40,80 \mathrm{lb} /$ acre $\mathrm{N},($ AS0, AS20, AS40, and AS80) and grower standard practice. The arrows indicate in-season fertilizer applications. Error bars represent the $\operatorname{SE}(n=4$ except for trial 3 , where $n=$ $3) ; 1 \mathrm{mg} \cdot \mathrm{kg}^{-1}=1 \mathrm{ppm}$.

increases the $\mathrm{NO}_{3}$ leaching hazard in the region. Over the growing season, $\mathrm{NO}_{3}$ levels in the soil can build up due to a combination of unused fertilizer and mineralization of crop residue and soil organic matter (Fig. 2C and D, Table 4).

These evaluations show that soil $\mathrm{NO}_{3}$ testing can be used to improve the NUE of spinach. Soil testing would be most effective in spinach production at two critical points: 1) at-planting and before the midseason fertilizer application when $\mathrm{N}$ use by spinach greatly increases (Fig. 1A). Soil $\mathrm{NO}_{3}$ concentrations $>20 \mathrm{mg} \cdot \mathrm{kg}^{-1} \quad \mathrm{NO}_{3}-\mathrm{N}$ were shown to be sufficient for lettuce grown in central California (Breschini and Hartz, 2002; Hartz et al., 2000), and the results from these evaluations show that this threshold is applicable to spinach.

For first-cropped fields with low residual soil $\mathrm{NO}_{3}$ levels, an at-planting fertilizer application was necessary to achieve maximum yields. Although $\mathrm{N}$ uptake in the first 2 weeks of the cropping cycle was low $(7.0 \mathrm{lb} /$ acre $\mathrm{N})$, $40 \mathrm{lb} /$ acre fertilizer $\mathrm{N}$ was necessary to build soil $\mathrm{NO}_{3}$ levels to $\geq 20$ ppm
(Fig. 2A and B) and to achieve maximum yields (Fig. 3A and B). These results indicate that spinach requires high soil $\mathrm{NO}_{3}$ levels early in the crop cycle, possibly to overcome intercrop competition in the high-density plantings. In addition, germination water in these studies was applied in excess of ETc to establish the crop (Table 5), which may leach soil $\mathrm{NO}_{3}$ beyond the reach of spinach roots. The choice of fertilizers is also important to prevent loss of at-planting fertilizer. $\mathrm{NH}_{4}$ or $\mathrm{NH}_{4}$-producing fertilizers may be a better choice than fertilizers containing 


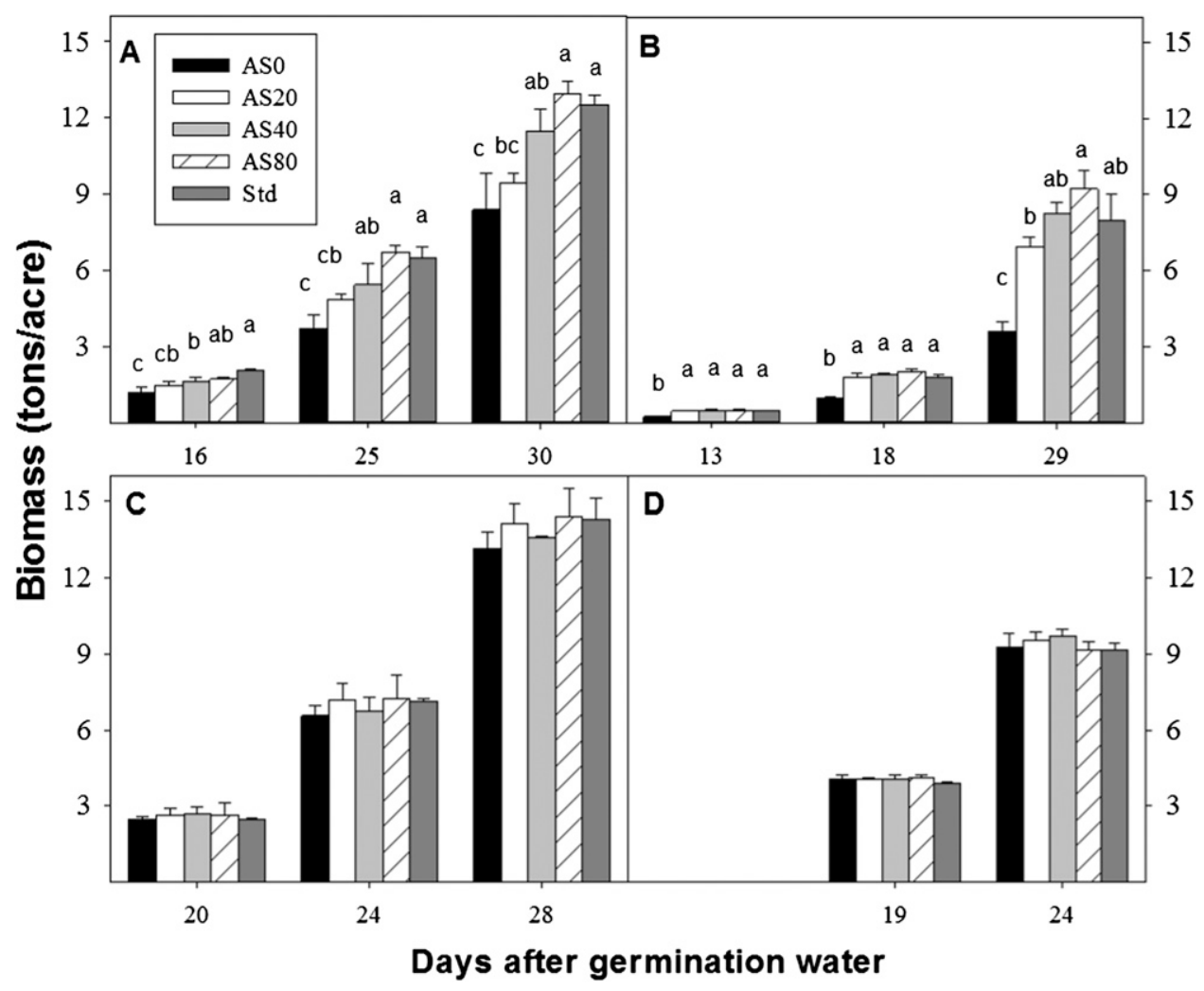

Fig. 3. Aboveground spinach fresh biomass for four replicated fertilizer trials in commercial spinach fields in the Salinas Valley and San Juan Valley of California: first-cropped fields (A) trial 1 and (B) trial 2, and second- and third-cropped fields (C) trial 3 and (D) trial 4. Fertilizer treatments are ammonium sulfate applied at a rate of $0,20,40,80 \mathrm{lb} / \mathrm{acre} \mathrm{N}$, (AS0, AS20, AS40, and AS80) and grower standard practice. Within each sampling date, bars with the same letter are not statistically different using Fisher's least-significant-difference test at $P>0.05$. For trial 3 and 4 , there was no significant difference in yield. Error bars

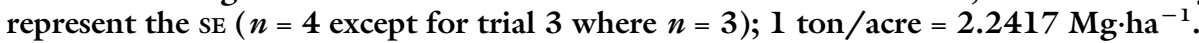

Table 5. Applied irrigation water and crop evapotranspiration (ETc) for fertilizer trials at field sites in commercial spinach fields sampled in 2011 in the Salinas Valley and San Juan Valley of California.

\begin{tabular}{|c|c|c|c|c|c|c|c|}
\hline \multirow[b]{3}{*}{ Site } & \multicolumn{3}{|c|}{ Germination } & \multicolumn{3}{|c|}{ Post-establishment } & \multirow[b]{3}{*}{ Total (inches) } \\
\hline & \multirow{2}{*}{\multicolumn{2}{|c|}{$(\text { inches })^{\mathrm{z}}$}} & \multirow{2}{*}{$\begin{array}{r}\text { Applied water } \\
(\% \mathrm{ETc})\end{array}$} & \multirow{2}{*}{\multicolumn{2}{|c|}{ (inches) }} & Applied water & \\
\hline & & & & & & $(\% \mathrm{ETc})$ & \\
\hline Trial 2 & 0.64 & 3.56 & 558 & 2.15 & 3.00 & 139 & 6.56 \\
\hline Trial 3 & 0.99 & 2.55 & 258 & 2.07 & 2.52 & 122 & 5.07 \\
\hline Trial 4 & 0.40 & 1.99 & 494 & 1.40 & 1.97 & 141 & 3.96 \\
\hline
\end{tabular}

${ }^{\mathrm{z}} 1$ inch $=2.54 \mathrm{~cm}$.

a significant portion of $\mathrm{NO}_{3}-\mathrm{N}$ because the positively charged $\mathrm{NH}_{4}$ ion is much less mobile in soil than $\mathrm{NO}_{3}$ and would be less likely to leach with the germination water.

The $\mathrm{N}$ management strategy for second-cropped fields was different from first-cropped fields. Residual soil $\mathrm{NO}_{3}$ remaining after harvest of the prior crop as well as $\mathrm{N}$ mineralizing from incorporated crop residues provided a substantial portion of the subsequent spinach crop's N requirements. Therefore, at-planting and possibly even midseason fertilizer applications for second-cropped fields could be reduced or, in some cases, eliminated without suffering a yield loss (Fig. 3C and D).

If residual soil $\mathrm{NO}_{3}$ levels are not accounted for and fertilizer is applied in excess of crop requirements, a large pool of $\mathrm{NO}_{3}$ may be left in the soil after harvest (Fig. 2C and D). Although any residual soil $\mathrm{NO}_{3}$ left by spinach after harvest may be used by a subsequent vegetable crop, it could also be at risk of loss to leaching during germination of the subsequent crop or during the winter fallow.

$\mathrm{N}$ management is incomplete without efficiently managing irrigations to minimize $\mathrm{NO}_{3}$ leaching below the crop's root zone. Fresh market spinach has a shallow root system (Table 6) and appears to be unable to effectively use $\mathrm{NO}_{3}$ deeper than 16 inches. Therefore, to maximize the NUE of spinach, $\mathrm{NO}_{3}$ movement below the root zone should be minimized by closely matching irrigations with crop water requirements. 


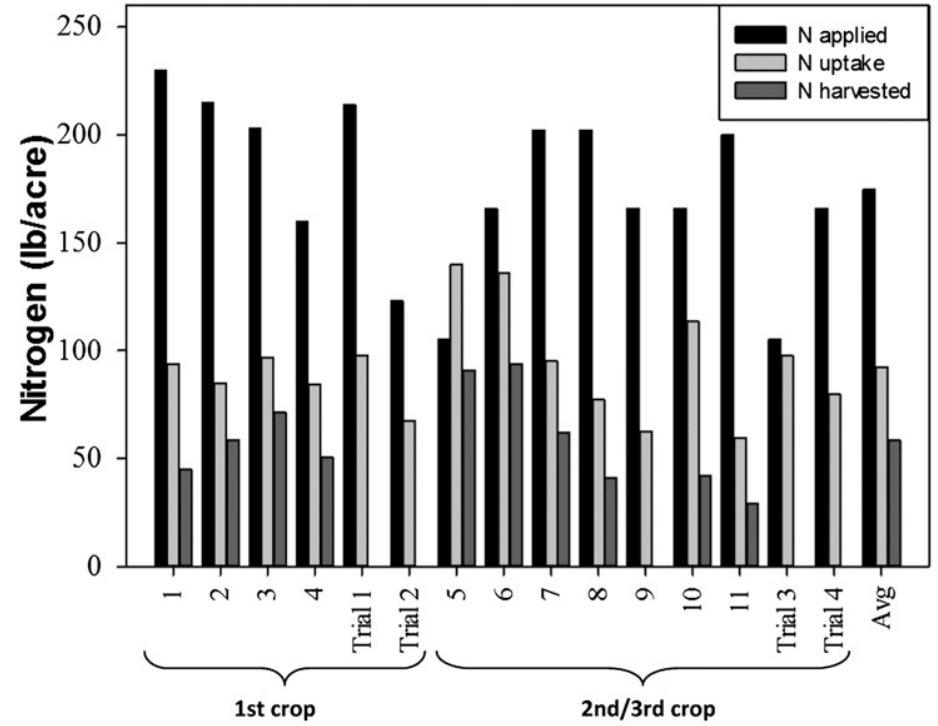

Fig. 4. Nitrogen (N) fertilizer applied during the crop cycle, spinach $\mathrm{N}$ uptake in aboveground biomass at harvest, and $\mathrm{N}$ removed from the field in the harvested product for fertilizer trials and survey sites in commercial spinach fields in the Salinas Valley and San Juan Valley of California. No N removal data were available from the fertilizer trials and survey site 9. The data are displayed in chronologic order by planting date, earliest to latest; $1 \mathrm{lb} / \mathrm{acre}=1.1209 \mathrm{~kg} \cdot \mathrm{ha}^{-1}$.

Table 6. Root density distribution in six soil depths at harvest for three fertilizer trials and one survey site in commercial spinach fields sampled in 2011 in the Salinas Valley and San Juan Valley of California.

\begin{tabular}{|c|c|c|c|c|c|c|c|}
\hline \multirow[b]{3}{*}{ Site } & \multicolumn{6}{|c|}{ Soil depth (inches) ${ }^{\mathrm{z}}$} & \multirow[b]{3}{*}{ Note } \\
\hline & $\overline{0-4}$ & $4-8$ & $8-12$ & $12-16$ & $16-2$ & $20-24$ & \\
\hline & \multicolumn{6}{|c|}{ (\% of total roots in each layer) } & \\
\hline Trial 1 & 42 & 27 & 22 & 7 & 1 & 1 & Dense plow pan at 12 inches \\
\hline Trial 3 & 40 & 32 & 15 & 9 & 2 & 2 & \\
\hline Trial 4 & 37 & 29 & 15 & 9 & 7 & 4 & Slight plow pan at 12 inches \\
\hline Site 4 & 57 & 34 & 3 & 2 & 2 & 1 & Clay layer at 12 inches \\
\hline Avg & 44 & 31 & 14 & 7 & 3 & 2 & \\
\hline
\end{tabular}

${ }^{2} 1$ inch $=2.54 \mathrm{~cm}$.

Table 7. Nitrate-nitrogen $(\mathrm{N})$ distribution in soil profile at harvest for three fertilizer trials and one survey site in commercial spinach fields sampled in 2011 in the Salinas Valley and San Juan Valley of California.

\begin{tabular}{|c|c|c|c|c|c|c|}
\hline \multirow[b]{3}{*}{ Site } & \multicolumn{6}{|c|}{ Soil depth (inches) ${ }^{\mathrm{z}}$} \\
\hline & $\overline{0-4}$ & $4-8$ & $8-12$ & $12-16$ & $16-20$ & $20-24$ \\
\hline & \multicolumn{6}{|c|}{ Nitrate-N (mg.kg ${ }^{-1}$ soil $)^{\mathrm{z}}$} \\
\hline Trial 1 & 13 & 4 & 1 & 4 & 7 & 8 \\
\hline Trial 3 & 4 & 1 & 5 & 10 & 17 & 21 \\
\hline Trial 4 & 138 & 33 & 14 & 15 & 18 & 20 \\
\hline Site 4 & 14 & 2 & 6 & 13 & 19 & 19 \\
\hline Avg & 42 & 10 & 6 & 10 & 15 & 17 \\
\hline
\end{tabular}

${ }^{2} 1$ inch $=2.54 \mathrm{~cm}, 1 \mathrm{mg} \cdot \mathrm{kg}^{-1}=1 \mathrm{ppm}$.

Reducing $\mathrm{N}$ use in spinach will be a challenge. The crop has a shallow root system, a high $\mathrm{N}$ demand, which occurs over a short period, and strict quality standards for a deep green color that tends to encourage $\mathrm{N}$ applications beyond the agronomic requirements to maximize yield. Addressing these challenges will require that fertilizer $\mathrm{N}$ is applied at the optimal time and rate based on crop uptake and soil $\mathrm{NO}_{3}$ testing, and that irrigation water is efficiently applied to minimize leaching and runoff.

\section{Literature cited}

AOAC International. 2006. Microchemical determination of carbon, hydrogen, and nitrogen, automated method (Official Method 972.43). Chapter 12, p. 5-6. In: Official methods of analysis of AOAC International. 18th ed. AOAC International, Gaithersburg, MD.

Bouyoucos, G.J. 1962. Hydrometer method improved for making particle size analysis of soil. Agron. J. 54:464465 .

Breschini, S.J. and T.K. Hartz. 2002. Presidedress soil nitrate testing reduces fertilizer use and nitrate leaching hazard in lettuce production. HortScience 37: 1061-1064.

Canali, S., F. Montemurro, F. Tittarelli, and O. Masetti. 2008. Effect of nitrogen fertilization reduction on yield, quality and $\mathrm{N}$ utilization of processing spinach. J. Food Agr. Environ. 6:242-247.

Canali, S., F. Montemurro, F. Tittarelli, and $\mathrm{O}$. Masetti. 2011. Is it possible to reduce nitrogen fertilization in processing spinach? J. Plant Nutr. 34:534-546.

Gallardo, M., R.L. Snyder, K. Schulbach, and L.E. Jackson. 1996. Crop growth and water use model for lettuce. J. Irrig. Drain. Eng. 122:354-359.

Harter, T. and J. Lund. 2012. Addressing nitrate in California's drinking water with a focus on Tulare Lake Basin and Salinas Valley groundwater. University of California, Davis. I Mar. 2013. <http:// groundwaternitrate.ucdavis.edu $>$.

Hartz, T.K., W.E. Bendixen, and L. Wierdsman. 2000. The value of presidedress soil nitrate testing as a nitrogen management tool in irrigated vegetable production. HortScience 35: 651-656.

Hofer, S. 2003. Determination of ammonia (salicylate) in $2 \mathrm{M} \mathrm{KCl}$ soil extracts by flow injection analysis. QuikChem Method 12-107-06-2-A. Lachat Instruments, Loveland, CO.

Jackson, L.E., L.J. Stivers, B.T. Warden, and K.K. Tanji. 1994. Crop nitrogen utilization and soil nitrate loss in a lettuce field. Fert. Res. 37:93-105.

Knepel, K. 2003. Determination of nitrate in $2 \mathrm{M} \mathrm{KCl}$ soil extracts by flow injection analysis. QuikChem Method 12-107-04-1-B. Lachat Instruments, Loveland, CO. 
Meyer, G.A. and P.N. Keliher. 1992. An overview of analysis by inductively coupled plasma-atomic emission spectrometry, p. 473-516. In: A. Montaser and D.W. Golightly (eds.). Inductively coupled plasmas in analytical atomic spectrometry. VCH Publishers, New York, NY.

Sah, R.N. and R.O. Miller. 1992. Spontaneous reaction for acid dissolution of biological tissues in closed vessels. Anal. Chem. 64:230-233.

Schenk, M., B. Heins, and B. Steingrobe. 1991. The significance of root development of spinach and kohlrabi for $\mathrm{N}$ fertilization. Plant Soil 135:197-203.

Thompson, T.L. and T.A. Doerge. 1995. Nitrogen and water rates for subsurface trickle-irrigated collard, mustard, and spinach. HortScience 30:1382-1387.

U.S. Department of Agriculture. 2011. California agricultural statistics 2010 crop year. U.S. Dept. Agr., Washington, DC.

U.S. Department of Agriculture. 2012. Vegetables 2011 summary. U.S. Dept. Agr., Washington, DC. 